\title{
Smoky indoor cooking fires are associated with elevated hemoglobin concentration in iron-deficient women
}

\author{
Lynnette M. Neufeld, ${ }^{1}$ Jere Douglas Haas, ${ }^{2}$ Marie T. Ruel, ${ }^{3}$ \\ Rubén Grajeda, ${ }^{4}$ and Luke P. Naeher ${ }^{5}$
}

Suggested citation Neufeld LM, Haas JD, Ruel MT, Grajeda R, Naeher LP. Smoky indoor cooking fires are associated with elevated hemoglobin concentration in iron-deficient women. Rev Panam Salud Publica. 2004; 15(2):110-18.

ABSTRACT Objective. Indoor air pollution from the burning of such biomass fuels as wood and agricultural waste is associated with a higher risk of a number of respiratory problems. The effect on other health outcomes, such as fetal growth, has not yet been adequately documented. The objective of this study was to determine whether, among women who burn biomass fuels for cooking indoors, the use of "smoky" fires is associated with elevated hemoglobin concentration in comparison to women using "smokeless" stoves, that is, stoves that are designed to reduce indoor air pollution. This research was conducted as part of a series of preliminary studies to determine the feasibility and potential health benefits of a randomized stove intervention to reduce indoor air pollution from the burning of biomass fuels for cooking.

Methods. A cross-sectional observational study was conducted in rural highland communities of Guatemala from March to August 1994. Venous blood samples were collected and analyzed for hemoglobin and ferritin. All the women studied burned biomass fuels and cooked indoors, and none of the women was pregnant. Eighty-nine indigenous women using smokeless stoves (designated as the not-exposed group) and 185 indigenous women from the same communities using smoky fires (the exposed group) were studied. Multiple linear regression analyses were used to investigate the relationship between exposure (smokeless stove or smoky fire) and hemoglobin concentration, with adjusting for potential confounding factors.

Results. No effect of exposure (smokeless stove or smoky fire) on hemoglobin concentration was found in univariate or multivariate analyses. In routine post hoc analysis to determine whether hemoglobin elevation is observed in some particular subgroup, we found that the use of a smoky fire was associated with a $5.2 \mathrm{~g} / L$ elevation in hemoglobin concentration among women with low ferritin stores $(\mathrm{P}<0.10)$.

Conclusions. The elevation of hemoglobin concentration through exposure to indoor air pollution resulting from the burning of biomass fuels in smoky fires for cooking could have important implications for the diagnosis of anemia. However, considering the observational nature of this study, further research using more rigorous measures of exposure to carbon monoxide as well as additional measures of iron status are needed to confirm the relationships

1 Instituto Nacional de Salud Pública, Centro de Investigación en Nutrición y Salud, Cuernavaca, Morelos, México. Send correspondence to: Lynnette M. Neufeld, División de Epidemiología de la Nutrición, Instituto Nacional de Salud Pública, Av. Universidad 655, Cuernavaca, Morelos, 62508,
México; e-mail: lneufeld@correo.insp.mx; telephone: (527)77-3293016.

2 Cornell University, Division of Nutritional Sciences, Ithaca, New York, United States of America. 3 International Food Policy Research Institute, Washington, D.C., United States.

\footnotetext{
4 Instituto de Nutrición de Centro América y Panamá, Guatemala, Guatemala.

5 Georgia State University, Department of Environmental Sciences, Atlanta, Georgia, United States.
} 
among iron status, exposure to smoke from the burning of biomass fuels indoors, and hemoglobin concentration of women living at moderately high altitude. Further study of this matter could help to assure that appropriate adjustments to anemia cutoffs are made, if warranted, and could assist in clarifying potentially negative outcomes of exposure to smoke from biomass fuels burned indoors.

Key words Hemoglobins; air pollution, indoor; anemia, iron deficiency; altitude; risk factors; Guatemala.

Studies of the negative effects of carbon monoxide $(\mathrm{CO})$ on human health have generally focused on acute and chronic exposure from cigarette smoke. Chronic exposure is associated with a number of negative health effects, including retarded fetal growth (1). Similarities between $\mathrm{CO}$ exposure from cigarette smoke and $\mathrm{CO}$ from the burning of biomass fuels (for example, wood, corn husks, and other agricultural wastes) indoors have been recognized (2). Around the world millions of people depend on biomass fuels for cooking and heating (3). The burning of biomass fuels results in the production of $\mathrm{CO}$ and particulates. In addition, in poor rural areas of developing countries, fires are often built indoors in homes with poor ventilation (2). Many negative health effects of air pollution resulting from the burning of biomass fuels indoors have now been documented $(3,4)$, including increased risk of chronic obstructive pulmonary disease (5) and acute respiratory disease (6). The groups most vulnerable to chronic exposure are women, who do the majority of the cooking, and small children, who are often in close proximity to their mothers (2). Although some evidence exists that the use of indoor fires for cooking may be associated with lower birthweight (7), this hypothesis has not yet been adequately tested. Other negative health outcomes may depend on specific circumstances such as duration and intensity of personal exposure, nutritional and health status, and interaction with other environmental and socioeconomic factors (3).

Hemoglobin $(\mathrm{Hb})$ concentrations are, on average, 3-5 g/L higher for individuals who smoke 20 to 40 cigarettes per day than they are for non- smokers $(8,9)$. Hb is elevated over the entire range in smokers, resulting in a right shift in the frequency distribution. $\mathrm{Hb}$ decreases within a month following smoking cessation $(10,11)$. The elevation of $\mathrm{Hb}$ because of $\mathrm{CO}$ inhalation may be interpreted as a functional adaptation to tissue hypoxia, and this adaptation could influence the diagnosis of anemia.

Anemia is a major public health problem in many parts of the world, but particularly among the rural poor in developing countries, where biomass fuels are commonly used (12). Adequate diagnosis of anemia is essential for screening individuals into programs, evaluating the effectiveness of interventions to improve iron status, and monitoring progress towards the goal of reducing the prevalence of anemia. Elevated $\mathrm{Hb}$ concentration as a result of exposure to $\mathrm{CO}$, if found to exist, could mask anemia and reduce the chances that vulnerable groups would be identified for intervention.

The severity of CO-induced hypoxia is related to percent carboxyhemoglobin $(\mathrm{COHb})$, that is, the percent of total $\mathrm{Hb}$ with the oxygen-carrying site occupied by $\mathrm{CO}$ (13). The affinity of $\mathrm{Hb}$ for $\mathrm{CO}$ is 200 times that for oxygen (14), so small changes in inspired air $\mathrm{CO}$ concentration greatly increase $\mathrm{COHb}$. Among smokers, values of $15 \%$ to $20 \%$ $\mathrm{COHb}$ have been reported $(10,11,15)$. Also in smokers, red cell mass has been found to be significantly correlated with $\mathrm{COHb}$ concentration (11), and a close relationship among $\mathrm{COHb}$ concentration, erythropoietin production, and $\mathrm{Hb}$ has been reported (16). It seems reasonable that if $\mathrm{COHb}$ levels are elevated due to exposure to $\mathrm{CO}$ from the smoke of biomass fires used indoors for cooking, $\mathrm{Hb}$ concentration will be elevated. Values of $13 \% \mathrm{COHb}$ were reported in cooks using biomass fuels in India, compared to 3\% in their noncooking counterparts (17).

The use of biomass fuels for cooking indoors is a common practice in many regions of the developing world. This presents a particular risk for exposure in mountainous areas where fires are built indoors, houses are enclosed to conserve heat, and the hypobaric hypoxia of high altitude is an additional stress to the hypoxemia of elevated $\mathrm{COHb}$. A further consideration in this population is the high prevalence of iron deficiency and iron deficiency anemia, which may further contribute to hypoxemia.

The study reported here tested the hypothesis that among nonpregnant women who use biomass fuels (wood and agricultural wastes) for cooking indoors, women using smoky fires (the exposed group) will have a higher $\mathrm{Hb}$ concentration for a given iron status than women using smokeless stoves for cooking (the not-exposed group) as a result of the first group's chronic exposure to $\mathrm{CO}$ from the cooking fires. This study was conducted as part of a series of pilot studies in preparation for a cooking stove intervention trial conducted by the Institute of Nutrition of Central America and Panama (INCAP) and the World Health Organization. As part of the intervention trial, homes currently using simple open fires for cooking were to be randomly assigned to receive a smokeless stove or to continue to use the open fire. The intervention was designed to measure the impacts that reducing indoor air pollution by using smokeless stoves would have on respiratory illness and on infant birthweight. (Unfortunately, during the time 
that this pilot study was conducted, the intervention trial did not receive funding.)

\section{MATERIALS AND METHODS}

\section{Study design, recruitment, and sample size}

A cross-sectional study was conducted in a rural highland region of Guatemala from March to August 1994. Participants in the study were all Mayan (Mam-speaking), and all interviews were conducted in Mam, with translation to Spanish. Each home in 17 small villages (caseríos) was visited. We invited women to participate who were between 15 and 45 years old, were the principal cook in the family, and were using a smokeless stove for cooking. The smokeless stoves were built on a waist-high platform made of brick, cement, or a combination of both. All stoves were designed to reduce indoor air pollution, and all used wood and/or agricultural waste, particularly corn husks, for fuel. Specifically, all stoves had a chimney, metal rings to place over the holes when pots were not on the stove, and a door that could be opened to add fuel to the fire. For a woman to be enrolled in the study, the chimney of her stove had to be functioning and there could be no evidence of smoke in the home while cooking, or soot on the walls or ceiling. Although all the stoves were made locally, their exact design varied slightly, such as with the construction materials, size of the cooking holes and door, and the diameter of the chimney tube. The families had acquired the stoves in a variety of ways, including purchase and assistance from local church and nongovernmental organizations. Women using smokeless stoves were considered the not-exposed group.

The two closest neighbors to each woman using the smokeless stove who were also 15-45 years of age and the principal cook in the family but who cooked on a "smoky" fire were then invited to participate. A fire was considered smoky if it was: (1) an open fire built on the floor of the house or (2) a fire built on some type of platform or structure with no chimney, with a chimney that was completely blocked, or with a chimney tube that was broken. In addition, the woman had to report that smoke regularly entered the room while she was cooking, and there had to be evidence of soot on the walls and ceiling. Women using smoky fires were considered the exposed group.

A detailed explanation of study objectives and procedures was provided to all potential participants in both groups, and each woman was asked to provide verbal informed consent for her agreement to participate.

Altitude has a considerable influence on $\mathrm{Hb}(18,19)$. The villages in our study were grouped at approximately 2200 to $2500 \mathrm{~m}$ ("lower" altitude), at the bottom of a mountain, and at approximately 2600 to $2900 \mathrm{~m}$ ("higher" altitude), higher up on that same mountain. The altitude of each village was estimated using topographical maps (20). Our sampling scheme of first identifying women using smokeless stoves and then inviting neighbors using smoky fires to participate was intended to ensure a relatively equal representation in the exposed group and the not-exposed group from the various altitudes, but it does not represent a truly matched design.

The expected difference in mean $\mathrm{Hb}$ between women using smoky fires (exposed group) and smokeless stoves (not-exposed group) was estimated at $3 \mathrm{~g} / \mathrm{L}$, that is, an amount similar to the difference in $\mathrm{Hb}$ between smokers and nonsmokers (21). The standard deviation for $\mathrm{Hb}(9 \mathrm{~g} / \mathrm{L})$ reported from one of the study villages (22) was used in the sample size calculation. Assuming a power of 0.9 and a probability of type I error of 0.05 , the required sample size was 155 per group (23).

\section{Data collection}

We used a questionnaire and observation to collect information on pregnancy, lactation, age, and socioeconomic status (SES). Regardless of cooking method (smoky fire or smoke- less stove), each woman was asked whether there was smoke in the room when she cooked, and observations were made for the presence of soot on the walls and ceiling. Windows and open spaces in the walls and roof were counted as a proxy for ventilation. All women who reported being pregnant or suspected that they were pregnant were excluded from the study. Height, weight, arm and calf circumference, and triceps and subscapular skinfold thickness were measured according to standard procedures (24) by a trained anthropometrist. Venous blood samples were taken using 8-mL heparinized Vacutainers (Becton Dickinson, Franklin Lakes, New Jersey, United States of America), analyzed immediately for $\mathrm{Hb}$ by a calibrated portable photometer (Hemocue Inc., Mission Viejo, California, United States), and then stored on ice. Hematocrit was assessed by microcentrifugation. Plasma was separated, frozen, and later analyzed for ferritin by enzyme immunoassay (Ramco Laboratories Inc., Houston, Texas, United States). All anemic women were provided with 3 months of ferrous sulfate tablets.

$\mathrm{CO}$ levels in the kitchen were measured on a subset of the sample by placing a Dräger passive diffusion tube (National Dräger Inc., Pittsburgh, Pennsylvania, United States) in the kitchen at the breathing level of the participant and left for 24 hours. The passive diffusion tubes undergo a color change from white to gray when $\mathrm{CO}$ reacts with the material in the tube. The tubes pose no health risks. Integrated 24-hour CO concentration (in ppm) was determined on site by measuring the height of the discoloration and dividing the total $\mathrm{CO}$ by the length of the measurement period. Each woman in this subset of the sample also wore a Dräger passive diffusion tube clipped to her clothing at shoulder level for the same 24 hours as a more direct measure of the woman's exposure to $\mathrm{CO}$. Inclusion in this subset was based on a woman's willingness to participate. Although the monitoring system that we report here is simplistic, it was found to be adequate to reflect ambient $\mathrm{CO}$ levels in these houses (25). 


\section{Data analysis}

Iron deficiency was defined as plasma ferritin $\leq 12 \mu \mathrm{g} / \mathrm{L}$ (21). Because plasma ferritin is not normally distributed, ferritin values were log transformed to permit statistical testing for differences between exposure groups, and the log transformed values were used in regression analysis. Anemia was defined as $\mathrm{Hb}<130 \mathrm{~g} / \mathrm{L}$ for lower altitude and as $<134 \mathrm{~g} / \mathrm{L}$ for higher altitude (19). Anthropometric measurements and indices of iron status were tested for differences between the exposed group and the not-exposed group by Student's $t$ test. The frequency distribution of $\mathrm{Hb}$ for each exposure group was plotted to observe whether an increase in $\mathrm{Hb}$ concentration among women using smoky fires for cooking compared to women using smokeless stoves was evident over the entire distribution of $\mathrm{Hb}$ concentrations.

Ordinary least squares regression was used to test the hypothesis that women who use smoky fires for cooking would have a higher $\mathrm{Hb}$ concentration in comparison to women using smokeless stoves, after adjusting for potential confounders. $\mathrm{Hb}$ was the dependent variable, and exposure group ( 0 = smokeless stove, $1=$ smoky fire $)$ was the independent variable. All analyses adjusted for age, iron deficiency $(0=$ adequate ferritin, $1=$ low ferritin), and altitude of residence ( $0=$ lower, 1 = higher) (26).

The influence of iron status on the relationship between exposure group (smokeless stove or smoky fire) and $\mathrm{Hb}$ was tested as an interaction between exposure and ferritin group in a routine post hoc examination of subgroups that might be more responsive to smoke inhalation. The influence of iron status on the relationship between altitude and $\mathrm{Hb}$ was tested in a similar manner.

An index was created based on the sum of 10 material possessions and used as an indicator of SES. Indices based on housing materials and possessions have been used in other studies in Guatemala $(27,28)$. We decided to use only the sum of possessions due to the high inverse correlation between better materials used for housing construction and cooking method. For example, the correlation between material used for floor construction in the house and cooking method was -0.56 ; that is, those who had better floor materials (e.g., cement instead of dirt) were less likely to use a smoky fire and more likely to use a smokeless stove.

$P$ values of $<0.05$ for main effects and $<0.10$ for interactions were considered statistically significant. All data were entered in Epi Info version 5.1 software (Centers for Disease Control and Prevention, Atlanta, Georgia, United States) and analyzed using SAS Windows version 6.01 software (SAS Institute Inc., Cary, North Carolina, United States). This study received clearance from the Committee for Human Subjects at Cornell University and from INCAP.

\section{RESULTS}

The sample consisted of 274 nonpregnant women, with 185 in the exposed group and 89 in the not-exposed group. We did not reach the estimated sample size for the smokeless stove (not-exposed) group because of the dif- ficulty in finding nonpregnant women who used smokeless stoves. Of the 185 women in the smoky fire (exposed) group, 51 of them used a fire on some type of platform that either lacked a chimney or had a nonfunctioning chimney (chimney completely blocked or chimney tube broken). The remaining 134 women in the smoky fire group used open fires on the floor. All 185 women in the smoky fire group reported that the room filled with smoke when the fire was lit, and there was evidence of soot on the walls and ceiling. The 51 women using some type of platform did not differ from the 134 other women in the exposed group in terms of anthropometry, iron status, or SES.

Of the 274 women, 145 of them $(53 \%)$ resided in the higher-altitude villages, and the remaining 129 (47\%) were in the lower-altitude villages. More women in the smoky fire (exposed) group resided at the higher altitude. Women in the smokeless stove (not-exposed) group were significantly taller, had a larger calf circumference, and had higher SES than did the smoky fire (exposed) group (Table 1 ). These differences do not change when women with incomplete blood data (see below) are excluded (data

TABLE 1. Comparison of anthropometric measures, iron status, and socioeconomic status among women using smoky fires (exposed group) or smokeless stoves (not-exposed group) for cooking indoors, Guatemala, $1994^{\mathrm{a}}$

\begin{tabular}{lcrr}
\hline \multicolumn{1}{c}{ Variable } & $\begin{array}{c}\text { Smoky fires } \\
(\text { mean } \pm \text { SD) }\end{array}$ & $\begin{array}{c}\text { Smokeless stoves } \\
\text { (mean } \pm \text { SD) }\end{array}$ & $P$ value $^{\mathrm{b}}$ \\
\hline Age $(\mathrm{yr})$ & $28.3 \pm 8.1$ & $28.4 \pm 7.9$ & 0.82 \\
Height $(\mathrm{cm})$ & $144.2 \pm 4.3$ & $145.5 \pm 4.8$ & $<0.05$ \\
Weight $(\mathrm{kg})$ & $46.2 \pm 6.1$ & $47.6 \pm 5.8$ & 0.06 \\
Arm circumference $(\mathrm{cm})$ & $25.3 \pm 2.4$ & $25.6 \pm 2.1$ & 0.33 \\
Calf circumference $(\mathrm{cm})$ & $31.0 \pm 2.1$ & $31.7 \pm 2.0$ & $<0.01$ \\
Triceps skinfold $(\mathrm{mm})$ & $25.0 \pm 6.9$ & $24.3 \pm 6.1$ & 0.60 \\
Subscapular skinfold $(\mathrm{mm})$ & $21.9 \pm 7.6$ & $22.8 \pm 8.1$ & 0.27 \\
Hemoglobin $(\mathrm{g} / \mathrm{L})$ & $138.0 \pm 12.0$ & $137.0 \pm 13.0$ & 0.20 \\
Hematocrit & $0.44 \pm 0.03$ & $0.44 \pm 0.03$ & 0.22 \\
Ferritin $(\mu \mathrm{g} / \mathrm{L})_{\text {Index of socioeconomic status }^{\mathrm{d}}}^{23.3 \pm 17.7}$ & $25.5 \pm 19.4$ & 0.06 \\
& $2.2 \pm 1.3$ & $3.2 \pm 1.6$ & $<0.001$ \\
\hline
\end{tabular}

a Residence at higher altitude: smoky fires (exposed) group, 109 of 185 women (59\%); smokeless stove (not-exposed) group, 36 of 89 women (40\%); $P<0.01$ for chi-square test of difference between groups in proportion living at higher altitude. ${ }^{\mathrm{b}} \mathrm{SD}=$ standard deviation.

${ }^{c} P$ value, using $t$ test for difference in means between smoky fires (exposed) group and smokeless stoves (not-exposed) group. $P$ value for ferritin is reported for log transformed values.

d Based on the sum of possessions of the household from a set of 10 possessions. 
not shown). There was no statistically significant difference between the exposed group and not-exposed group for any of the indicators of iron status.

There was no difference in mean ferritin or age between those living at lower altitude and those at higher altitude $(P>0.30)$. Nor were there significant differences in mean ferritin or age between the exposure groups when tested as a whole (Table 1) or when divided by altitude of residence $(P>$ 0.20 for all comparisons). None of the women in this sample smoked cigarettes. There was no difference in the presence of a smoker in the home between exposure groups, those living at lower compared to higher altitude, or women with low compared to adequate ferritin (chi-square test, $P>0.40$ for all comparisons). The sum of possessions variable (our measure of SES) was not different between those with low compared to adequate ferritin $(P>$ 0.30 ). The sum of possessions variable was still statistically significantly different between exposure groups when the sample was further divided either by altitude of residence or by ferritin group $(P<0.01)$.

The frequency distribution of $\mathrm{Hb}$ concentration by exposure group (smoky fire vs. smokeless stove) is shown in Figure 1 for all the 274 women. There was no difference in frequency distribution of $\mathrm{Hb}$ between exposure groups, nor did the mean $\mathrm{Hb}$ concentration differ between them. Mean ( \pm standard deviation) $\mathrm{Hb}$ was $138 \mathrm{~g} / \mathrm{L}( \pm 12 \mathrm{~g} / \mathrm{L})$ in the smoky fire (exposed) group (185 women) and $137 \mathrm{~g} / \mathrm{L}( \pm 13 \mathrm{~g} / \mathrm{L})$ in the smokeless stove (not-exposed) group ( 89 women).

Complete blood data (ferritin and hemoglobin concentration) were available for 253 of the 274 women. For 16 of the 274 women, ferritin analysis was not available due to an insufficient sample to conduct the analysis or hemolyzation of the sample. An additional 5 women with ferritin values greater than $90 \mu \mathrm{g} / \mathrm{L}$ ( $>3$ standard deviations above the sample mean) were excluded from the regression analysis and the prevalence estimates of low ferritin and $\mathrm{Hb}$ because these ferritin values may not reflect iron status (26).
FIGURE 1. Frequency distribution of actual hemoglobin concentration in women using smoky fires (exposed group) and smokeless stoves (not-exposed group) for cooking, Guatemala, 1994

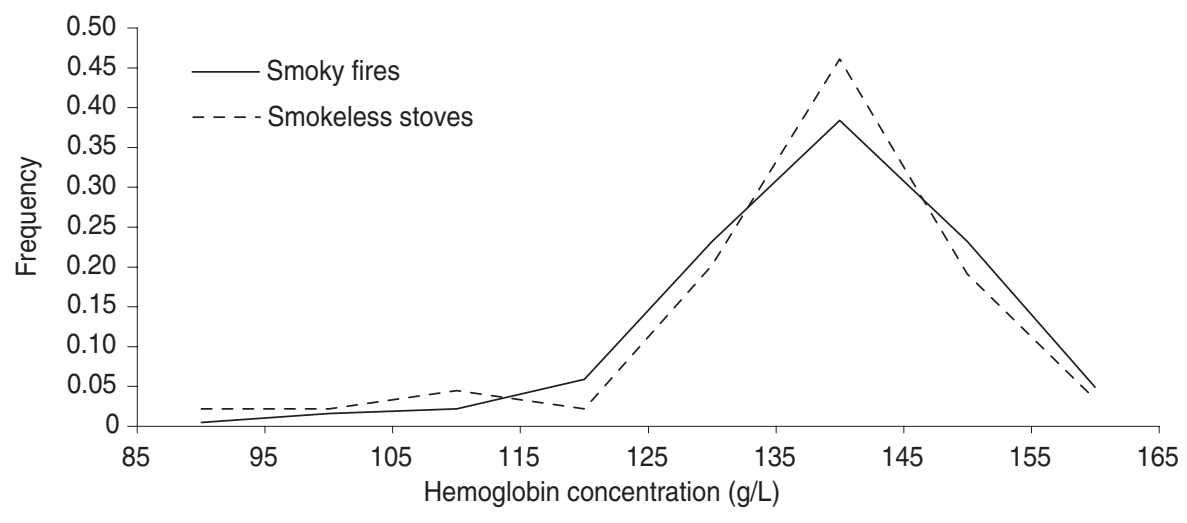

Four of these 5 women belonged to the exposed group, and one was from the not-exposed group. There was no statistically significant difference in the percent of women with low $\mathrm{Hb}$ or low ferritin between those using smoky fires and those using smokeless stoves (Table 2).

Integrated 24-hour kitchen CO concentration was significantly higher among the exposed group $(P<0.0001$, one-sided $t$ test), and there was a tendency for the level of $\mathrm{CO}$ in the monitor worn by the women in the exposed group to be higher than the level of $\mathrm{CO}$ in the not-exposed group $(P<0.10)$ (Figure 2). (Figure 2 presents data for 29 women in the not-exposed (smokeless stoves) group. Data for the exposed (smoky fire) group came from

26 women for the kitchen monitor and from 25 women for the personal monitor, since the personal monitor was lost for one of these women.) The two highest values of $\mathrm{CO}$ exposure on the personal monitor in the smokeless stove group were found for women who entered a temascal, a steam bath created by boiling water over an open wood fire in a small adobe structure. Excluding the data from these two women, the mean $\mathrm{CO}$ on the personal monitor worn by the women in the not-exposed group was significantly lower than the mean for the women in the exposed group $(P<0.001)$.

In multiple regression analysis, no statistically significant association between exposure group (smoky fire or smokeless stove) and $\mathrm{Hb}$ concentra-

TABLE 2. Percent of women with low ferritin or with low hemoglobin, for all women with complete blood analysis, by exposure group, Guatemala, 1994a

\begin{tabular}{|c|c|c|c|c|c|c|c|}
\hline & \multicolumn{2}{|c|}{$\begin{array}{c}\text { All } \\
\text { women } \\
(n=253)\end{array}$} & \multicolumn{2}{|c|}{$\begin{array}{c}\text { Smokeless } \\
\text { stove } \\
(n=82)\end{array}$} & \multicolumn{2}{|c|}{$\begin{array}{c}\text { Smoky } \\
\text { fire } \\
(n=171)\end{array}$} & \multirow{2}{*}{$\begin{array}{c}P \\
\text { value }^{b}\end{array}$} \\
\hline & No. & $\%$ & No. & $\%$ & No. & $\%$ & \\
\hline Low ferritin $(\leq 12 \mu \mathrm{g} / \mathrm{L})$ & 78 & 31 & 26 & 32 & 52 & 30 & 0.83 \\
\hline Low hemoglobin ${ }^{c}$ & 63 & 25 & 19 & 23 & 44 & 26 & 0.67 \\
\hline
\end{tabular}


FIGURE 2. Box plots of carbon monoxide (CO) concentration in parts per million (ppm) measured on a kitchen monitor and on a personal monitor worn by each woman over one 24-hour measuring period, Guatemala, 1994

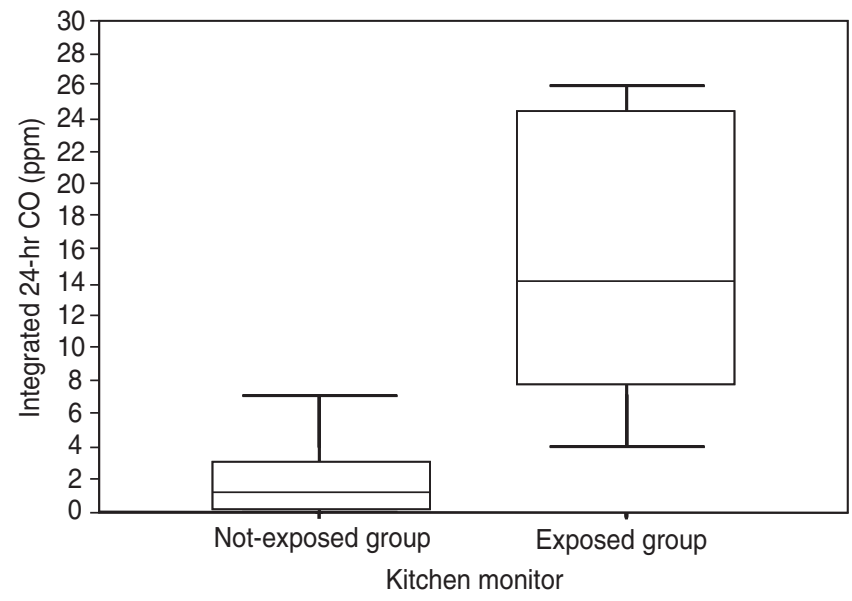

tion was found (Table 3). Both altitude of residence and ferritin group were significantly associated with $\mathrm{Hb}$ in the expected directions. Residence in the higher-altitude villages was associated with an $\mathrm{Hb}$ difference of $+3.6 \pm 1.4 \mathrm{~g} / \mathrm{L}$ $(\beta$ (regression coefficient) \pm standard error (SE), $P<0.01$ ). There was no evidence that the association between altitude and $\mathrm{Hb}$ concentration is dependent on iron status. This was tested as

(Table 3).

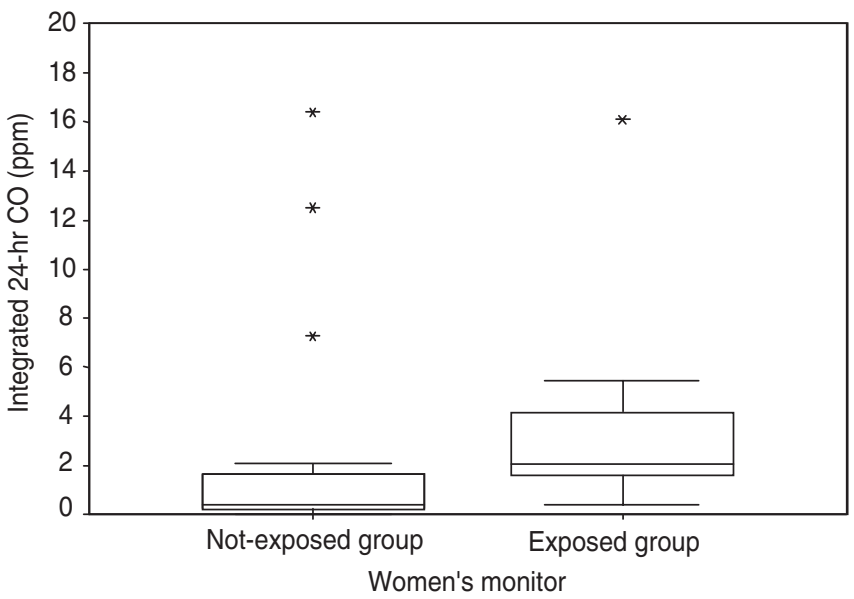

Neither SES nor house ventilation had a significant influence on $\mathrm{Hb}$ concentration, nor did their exclusion from the models alter the magnitude or statistical significance of the other coefficients. Therefore, they were excluded from the models shown here.

\section{DISCUSSION}

Results of the univariate as well as multivariate analyses indicate that across the entire sample of women there was no main effect of the use of smoky fires for cooking on women's $\mathrm{Hb}$ concentration. Power to detect this difference may have been limited since the power for our sample size was 0.65 . We were unable to find enough smokeless stoves that had a functioning chimney to meet our estimated sample size in the study communities. We decided not to expand the recruitment area due to limited resources and also to ensure that we would not introduce bias in the results due to other differences between regions. It is important to note that some stoves supposedly designed to reduce air pollution from the burning of biomass fuels indoors for cooking did not have a functioning chimney. We did not include these in our smokeless stove group, in an effort to avoid crossover between the exposed and not-exposed 
groups. This emphasizes the importance of adequate construction and maintenance of smokeless stoves when biomass fuels are used for cooking.

The 24-hour integrated CO concentrations assessed in the subset of our sample suggests that, on average, women in the smoky fire group were exposed to higher $\mathrm{CO}$ concentrations than were women in the smokeless stove group. Nonetheless, it is likely that all the participants in our study were exposed to smoke from biomass fuels to some degree. All participants in both the smoky fire and smokeless stove groups burned biomass fuels indoors for cooking. Exposure to $\mathrm{CO}$ while cooking may differ by type of fuel used (e.g., green or dry wood, agricultural wastes) and by cooking methods used (e.g., leaning directly over the fire or stove and keeping the door of the smokeless stove open). Because of the extremely cool temperatures in the region, houses are constructed to ensure minimum ventilation; this likely results in some $\mathrm{CO}$ in the kitchen, even among smokeless stove users. Finally, women in both groups may be exposed to $\mathrm{CO}$ from neighboring homes and from use of the temascal (traditional steam bath). The 24-hr integrated CO concentrations from homes with smokeless stoves provides evidence that, in effect, women in the smokeless stove group were exposed to $\mathrm{CO}$, albeit at lower levels than were the users of smoky fires. Thus, is it likely that in this population, exposure to $\mathrm{CO}$ is a continuum, whereby, at best, our observational study was able to distinguish between the extremes of exposure. Exposure to $\mathrm{CO}$ can be estimated by carboxyhemoglobin concentration. Unfortunately, for logistic reasons, assessment of carboxyhemoglobin was not feasible in this study. Instead, we relied on cooking method (smoky fire or smokeless stove) as a proxy for exposure. Estimates of individual carboxyhemoglobin concentration at various times during the day to quantify each woman's CO exposure would be useful to confirm the association between the use of smoky fires for cooking and elevated $\mathrm{Hb}$ concentration.
Recognizing the limitations of our observational study, we made every attempt to minimize confounding. Smoking, altitude, age, and iron status are all known determinants of $\mathrm{Hb}$ concentration and thus may confound the relationship (29). There was no difference in the number of homes with a smoker present between exposure groups nor between those living at higher compared to lower altitude or those with low compared to adequate ferritin. The housing clusters are located on the same mountain, at its base (the loweraltitude villages) or higher up on the mountain (the higher-altitude villages). The mean altitude is $2350 \mathrm{~m}$ among the lower-altitude villages and $2750 \mathrm{~m}$ among the higher-altitude villages. Based on the research by Cohen and Haas (19), the expected difference in $\mathrm{Hb}$ between these altitudes is approximately $4 \mathrm{~g} / \mathrm{L}$, which was very close to our finding of $3.6 \mathrm{~g} / \mathrm{L}$. Thus, our classification appears adequate to capture altitude differences in our population. The lack of systematic differences in age or ferritin concentration between those living at lower and higher altitude and those with lower and adequate ferritin provides support that our findings are not due to residual confounding. Other potential confounders related to SES (e.g., hypoxia due to noninfectious lung disease; better diet) could result in a higher $\mathrm{Hb}$ concentration. Thus, the group of women who used smokeless stoves but had low ferritin may be different from the smokeless stove users who had adequate ferritin. For example, the smokeless stove users with lower ferritin may have lower SES compared to smokeless stove users with adequate ferritin in the sample and thus be at greater risk for low $\mathrm{Hb}$ due to iron deficiency anemia. In this study we found that women using smokeless stoves had higher SES than those using smoky fires. Thus, although our measure of SES was not a significant predictor of $\mathrm{Hb}$ concentration in the regression analysis, this simple measure was able to pick up variability in SES, and we do not believe that the relationship between the use of smoky fires for cooking and elevated $\mathrm{Hb}$ concentration among women with low ferritin is due to residual confounding related to SES.

The existence of a statistically significant interaction between ferritin and cooking method (smokeless stoves or smoky fires) revealed that $\mathrm{Hb}$ concentrations were higher in those women exposed to smoky fires who had lower serum ferritin levels. This seems counterintuitive since one might expect that hemoglobin would be elevated in those women with adequate iron reserves. However, there is precedent in the literature to support the validity of our observations. Moreno-Black et al. (30) estimated total body iron in nonanemic women living at high or at low altitude using the algorithm of Cook et al. (31). Total body iron did not differ between women living at high altitude and those living at low altitude. Nonetheless, the $\mathrm{Hb}$ concentration was higher and the ferritin lower among women living at high altitude compared to women living at low altitude. The difference in iron status measures may be due to differences in the distribution of iron between $\mathrm{Hb}$ and liver storage (32). The higher $\mathrm{Hb}$ at high altitude may reflect an even greater proportion of body iron in the more functional form, $\mathrm{Hb}$ (18), with less iron available for storage in the liver resulting in lower ferritin levels. In our study, women using smoky fires who had low ferritin may have been exposed to higher $\mathrm{CO}$ concentrations than women using smoky fires who had adequate ferritin. Thus, among women with low ferritin who were exposed to $\mathrm{CO}$ from smoky fires, iron may have been diverted from liver stores for hemopoiesis without a concomitant increase in iron availability resulting from increased dietary iron absorption. In this scenario of adequate total body iron, low ferritin levels do not enhance the response of $\mathrm{Hb}$ to $\mathrm{CO}$ but are a consequence of this response. Clearly, research needs to be done to confirm this hypothesis by first showing that total body iron stores are indeed finite in iron-replete individuals experiencing chronic hypoxic stress.

Around the world, millions of women are exposed to $\mathrm{CO}$ from the burning of biomass fuels for cooking 
indoors. The elevation of hemoglobin concentration through exposure to indoor air pollution resulting from the burning of biomass fuels in smoky fires for cooking could have important implications for the diagnosis of anemia. It is precisely among the populations most at risk for anemia, that is, women living in poor rural areas of developing countries, that the use of biomass fuels for cooking is most common.

Further research using more rigorous measures of exposure to carbon monoxide as well as additional measures of iron status are needed to confirm the relationships among iron status, exposure to smoke from the burning of biomass fuels indoors, and hemoglobin concentration of women living at moderately high altitude. Further clarification of this matter could help to assure that appropriate adjustments to anemia cutoffs are made, if warranted.

Finally, the elevation in $\mathrm{Hb}$ associated with smoky fire use among women with low ferritin concentration observed in this study was similar to that reported for women who smoke 20 cigarettes a day. This level of cigarette smoking is associated with decreased mean birthweight and an increase in the prevalence of low birthweight $(33,34)$; this is also true for the inhalation of passive cigarette smoke $(34,35)$. The influence that CO inhalation from cooking smoke during pregnancy has on fetal growth should be evaluated.

Acknowledgements. Funding for this study came from the Canadian International Development Agency Awards for Canadians; the World
Health Organization; the International Development Resource Centre, Ottawa, Canada; the Division of Nutritional Sciences, Cornell University, Ithaca, New York, United States; and the National Institute of Environmental Health Science, Washington, D.C., United States (grant number R01ES05410). The authors would like to thank the field staff in Guatemala, the laboratory staff at INCAP, and the many women who agreed to participate in the study. We also gratefully acknowledge the contributions of Dr. Kirk Smith (Center for Occupational and Environmental Health, University of California, Berkeley) and Dr. Brian Leaderer (Department of Epidemiology and Public Health, Yale University School of Medicine) in the environmental monitoring component of this study.

\section{REFERENCES}

1. Kramer MS. Determinants of low birth weight: methodological assessment and metaanalysis. Bull WHO. 1987;65:663-737.

2. Smith KR. Biofuels, air pollution, and health: a global review. New York: Plenum Press; 1987.

3. Ezzati M, Kammen DM. The health impacts of exposure to indoor air pollution from solid fuels in developing countries: knowledge, gaps and data needs. Environ Health Perspect. 2002;110:1057-1068.

4. Smith KR. Indoor air pollution in developing countries: recommendations for research. Indoor Air. 2002;12:198-207.

5. Kiraz K, Kart L, Demir R, Oymak S, Gulmez I, Unalacak M, et al. Chronic pulmonary disease in rural women exposed to biomass fumes. Clin Invest Med. 2003;26:243-248.

6. Mishra V. Indoor air pollution from biomass combustion and acute respiratory illness in preschool age children in Zimbabwe. Int J Epidemiol. 2003;32:847-853.

7. Boy E, Bruce N, Delgado H. Birth weight and exposure to kitchen wood smoke during pregnancy in rural Guatemala. Environ Health Perspect. 2002;110:109-114.

8. United States, Centers for Disease Control and Prevention. CDC criteria for anemia in children and childbearing-aged women. MMWR Morb Mortal Wkly Rep. 1989;38(22): 400-404.

9. Shimakawa T, Bild DE. Relationship between hemoglobin and cardiovascular risk factors in young adults. J Clin Epidemiol. 1993;46:12571266.

10. Smith JR, Landaw SA. Smokers' polycythemia. New Engl J Med. 1978;298:6-10.
11. Calverley PMA, Leggett RJ, McElderry L, Flenley DC. Cigarette smoking and secondary polycythemia in hypoxic cor pulmonale. Amer Rev Resp Dis. 1982;125:507-510.

12. United Nations, Administrative Committee on Coordination/Sub-Committee on Nutrition. Fourth report on the world nutrition situation. Nutrition throughout the life cycle. Geneva: ACC/SCN, International Food Policy Research Institute; 2000.

13. Haab P. The effect of carbon monoxide on respiration. Experientia. 1990;46:1202-1206.

14. Longo LD. The biological effects of carbon monoxide on the pregnant woman, fetus, and newborn infant. Am J Obstet Gynecol. 1977; 129:69-103.

15. Sagone AL, Lawrence T, Balcerzak SP. Effect of smoking on tissue oxygen supply. Blood. 1973;41:845-851.

16. Jelkmann W, Kurtz A, Bauer C. Extraction of erythropoietin from isolated renal glomeruli of hypoxic rats. Exp Hematol. 1983;11:581588.

17. Behera D, Dash S, Yadav SP. Carboxyhemoglobin in women exposed to different cooking fuels. Thorax. 1991;46:344-346.

18. Ballew C, Garruto RM, Haas JD. High-altitude hematology: paradigm or enigma? In: Little MA, Haas JD, eds. Human population biology: a transdisciplinary science. New York: Oxford University Press; 1989. Pp. 239-262.

19. Cohen JH, Haas JD. Hemoglobin correction factors for estimating the prevalence of iron deficiency anemia in pregnant women residing at high altitudes in Bolivia. Rev Panam Salud Publica. 1999;6(6):392-399.
20. Guatemala, Instituto Geográfico Nacional. Mapa topográfico de Guatemala. Guatemala, Guatemala: IGN; 1960.

21. Pilch SM, Senti FR. Assessment of the iron nutritional status of the U.S. population based on data collected in the Second National Health and Nutrition Examination Survey, 1976-1980. Bethesda, Maryland, United States: Life Sciences Research Office, Federation of American Societies for Experimental Biology; 1984.

22. Dary O, Pineda O, Belizán JM. Carbon monoxide contamination in dwellings in poor rural areas of Guatemala. Bull Environ Contam Toxicol. 1981;26:24-30.

23. Snedecor GW, Cochran WG. Statistical methods. 8th ed. Ames, Iowa, United States: Iowa State University Press; 1989.

24. Lohman TG, Roche AF, Martorell R. Anthropometric standardization reference manual. Champaign, Illinois, United States: Human Kinetics; 1988.

25. Naeher LP, Smith KR, Leaderer BP, Neufeld L, Mage D. Carbon monoxide as a tracer for assessing exposures to particulate matter in wood and gas cookstove households of highland Guatemala. Environ Sci Technol. 2001;35: 575-581.

26. Gibson RS. Principles of nutritional assessment. New York: Oxford University Press; 1990.

27. Lechtig A, Delgado H, Yarbrough C, Habicht JP, Martorell R, Klein RE. A simple assessment of the risk of low birth weight to select women for nutritional intervention. Am J Obstet Gynecol. 1976;125:25-34. 
28. Rivera JA, Martorell R, Ruel MT, Habicht JP, Haas JD. Nutritional supplementation during preschool years influences body size and composition of Guatemalan adolescents. J Nutr. 1995;125( Suppl 4):1068S-1077S.

29. Bruce N, Neufeld LM, Boy E, West C. Quantifying the effect of indoor biofuel air pollution on respiratory health in observational studies: the role of confounding factors among women in highland Guatemala. Int J Epidemiol. 1998; 27:454-458.

30. Moreno-Black G, Quinn V, Haas JD, Franklin $\mathrm{J}$, Berard J. The distribution of haemoglobin concentration in a sample of native high altitude women. Ann Hum Biol. 1984;11:317-325.
31. Cook JD, Skikne BS, Lynch SR, Reusser ME Estimates of iron sufficiency in the US population. Blood. 1986;68:726-731.

32. Haas JD. Distribución de la hemoglobina en individuos normales residentes a gran altitud en Bolivia. In: Berger J, San Miguel JL, Arze RM, Fernández E, Aguayo VM, eds. Anemia por deficiencia de hierro en la región andina: definición y estrategias de intervención. La Paz, Bolivia: Institut Français de Recherche Scientifique pour le Développement en Coopération; 1996. Pp. 55-77.

33. Cliver SP, Goldenberg RL, Cutter GR, Hoffman HJ, Davis RO, Nelson KG. The effect of cigarette smoking on neonatal anthropo- metric measurements. Obstet Gynecol. 1995; 85:625-630.

34. Roquer JM, Figueras J, Botet F, Jiménez R. Influence on fetal growth of exposure to tobacco smoke during pregnancy. Acta Paediatr. 1995; 84:118-121.

35. Misra DP, Nguyen RH. Environmental tobacco smoke and low birth weight: a hazard in the workplace? Environ Health Persp. 1999;107:879-904.

Manuscript received 29 January 2003. Accepted for publication on 9 July 2003.
RESUMEN

\section{Asocian el fuego con humo para cocinar dentro de la vivienda con concentraciones elevadas de hemoglobina en mujeres con deficiencia de hierro}

Objetivo. La contaminación del ambiente doméstico por la combustión de materiales bioorgánicos utilizados como combustible, tales como la madera y los desechos agrícolas, está asociada con un mayor riesgo de padecer problemas respiratorios. Su efecto sobre otros aspectos de la salud, como el crecimiento fetal, no ha sido aún documentado adecuadamente. El objetivo del presente estudio, realizado en mujeres que utilizan combustible bioorgánico para cocinar en el interior de sus viviendas, fue determinar si el empleo de fuego "con humo" se asocia con una mayor concentración de hemoglobina en comparación con el uso de fogones "sin humo," es decir, cocinas diseñadas para reducir el nivel de contaminación del aire en el interior de las viviendas. Esta investigación es parte de una serie de estudios preliminares realizados para determinar la factibilidad y los posibles beneficios para la salud de una intervención aleatorizada dirigida a las cocinas, con el fin de reducir la contaminación del aire doméstico provocada por el empleo de combustibles bioorgánicos para cocinar.

Métodos. Entre marzo y agosto de 1994 se realizó un estudio observacional transversal en mujeres indígenas que utilizaban combustible bioorgánico y cocinaban en el interior de sus viviendas en comunidades rurales de las zonas montañosas de Guatemala. Se estudió a 89 mujeres que empleaban fogones sin humo (grupo no expuesto) y 185 mujeres de las mismas comunidades que empleaban fogones que generaban humo (grupo expuesto). Ninguna estaba embarazada. Se tomaron muestras de sangre venosa y se determinaron las concentraciones de hemoglobina y de ferritina. Mediante análisis de regresión lineal múltiple se investigó la relación entre la exposición (fogones sin humo o fogones con humo) y la concentración de hemoglobina, y se hicieron ajustes por posibles factores de confusión.

Resultados. No se encontró que la exposición al factor estudiado (fogones sin humo o con humo) tuviera algún efecto en la concentración de hemoglobina, ya fuera mediante análisis con una sola variable o con varias. Durante el análisis post hoc habitual para determinar si algún subgrupo particular presentaba elevación de la concentración de hemoglobina, se encontró que el empleo de fuego con humo para cocinar estaba asociado en grado significativo con la elevación de la concentración de hemoglobina en 5,2 g/L entre las mujeres con concentraciones bajas de ferritina $(P<0,10)$. Conclusiones. La elevación de la concentración de hemoglobina debida a la exposición al aire doméstico contaminado por el empleo de combustible bioorgánico en fogones de cocina que producen humo podría tener implicaciones importantes para el diagnóstico de la anemia. Sin embargo, debido a la naturaleza observacional de este estudio, se requieren nuevas investigaciones donde se usen métodos más rigurosos para medir la exposición al monóxido de carbono y se realicen más mediciones de la cantidad de hierro en el organismo para confirmar la relación entre esta, la exposición al humo procedente de la combustión de materiales bioorgánicos para cocinar dentro de la vivienda y la concentración de hemoglobina en mujeres que viven a altitudes moderadamente altas sobre el nivel del mar. Estudios adicionales en este sentido podrían contribuir a que se ajusten los puntos de corte empleados para el diagnóstico de la anemia, si se justificara, y podrían ayudar a aclarar el posible efecto negativo de la exposición al humo producido por la combustión de materiales bioorgánicos dentro de las viviendas. 